\title{
An investigation of leg and shoulder muscle strength ratios of elite female volleyball players
}

\author{
Cengiz AKARCESME ${ }^{1}$, Zait Burak AKTUG ${ }^{2}$, Hasan AKA ${ }^{3}$, Serkan IBIS ${ }^{2}$ \\ ${ }^{1}$ Gazi University, Faculty of Sport Sciences, Ankara, Turkey. \\ 2 Niğde Ömer Halisdemir University, School of Physical Education and Sports, Niğde, Turkey. \\ ${ }^{3}$ Gazi University, Health Sciences Institute, Ankara, Turkey. \\ Address correspondence to Z. B. Aktug, e-mail: zaitburak@gmail.com
}

\begin{abstract}
Providing muscular strength balance is an important factor in both improving sport performance and preventing sports injuries. The aim of the current study is to determine the leg and shoulder muscle strength ratios of elite female volleyball players. 14 elite voluntary female volleyball players were included in the study. Dominant (D) and nondominant (ND) knee and shoulder muscle strength ratios of volleyball players who participated in the study were determined by isokinetic dynamometer at $60^{\circ} \mathrm{s}-1$ and $180^{\circ} \mathrm{s}-1$ angular speeds. Bilateral force differences (BLD), leg hamstring / quadriceps ratio (H/Q) and shoulder external / internal ratio (E/I) averages and standard deviations were determined for the leg and shoulder muscles after the obtained data were applied to the SPSS program. Statistical analysis revealed that the H/Q ratio was low and the E/I ratio was high at $60^{\circ} \mathrm{s}^{-1}$ and $180^{\circ} \mathrm{s}^{-1}$ angular velocities. It was also been determined that the BLD of the shoulder muscles was high while the BLD of the leg muscles was at the desired level at $60^{\circ} \mathrm{s}^{-1}$ and $180^{\circ} \mathrm{s}^{-1}$ angular speeds. As a result, the volleyball players participating in the study seem to have lower leg muscle strength and lower H/Q ratio. Furthermore, although it is thought that more work is done with the upper extremity in the volleyball, it can be said that lower extremity force development should not be ignored since it is a well-known fact that the entire body is carried by the lower extremity to change rapidly.
\end{abstract}

Keyword: isokinetic strength, leg, shoulder, volleyball.

\section{INTRODUCTION}

The ability of the athlete to exhibit the highest strength available to them and the weakest strength of the muscles and muscle groups they have suggest that the force balance between the muscles is more important than the highest force available (4). This muscle strength balance is of great importance in the lower extremity with hamstring/quadriceps ratio $\mathrm{H} / \mathrm{Q}(17)$ and in the upper extremity with shoulder external / internal rotation ratio (E/I) (2). Ivey et al. (12) found that active and inactive persons had $2 / 3$ of the shoulder E/I ratio, while studies in the current literature suggested that the H/Q ratio should be $3 / 2$ (5).

Another important factor in muscle strength balance is the force ratio between bilateral muscles (BLD). When the literature is examined it is stated that BLD should be less than $10 \%$ (1.6). These muscle strength rates have an important effect both on enhancing sportive performance and preventing injuries caused by athletes lacking muscle strength (17).

There is a high incidence of sports injuries during volleyball games. Solgard et al. (22) reported that volleyball injuries ranked 4th among all sports branches. Sports injuries are more likely to be seen in sport branches that require jumping, leaping and rapid change $(15,19)$. The basic movements of volleyball are jumping during the block and spike and it is known that during the practice of many volleyball-specific movements they change fast. The frequent use of such movements in volleyball increases the likelihood of injury within this branch (22). However, it is now possible with isokinetic dynamometers to predict the likelihood of injury and determine which muscles are weak causing these injuries (18).

In the lights of the knowledge, the purpose of the study is to determine the level of leg and shoulder isokinetic muscle strength in elite female volleyball 
players, which is an important factor in both improving sport performance and preventing sports injuries.

\section{MATERIALS \& METHODS}

Fourteen voluntary female volleyball players participated in the 2016-2017 season playing in Halkbank sports club in Sultan League. The procedure of the measurements of female volleyball players participating in the study was as follows; isokinetic leg and shoulder strength were measured with a Tanita BC-418 Segmental Body Analysis System (Tanita Corporation, Tokyo, Japan) a standard steel stadiometer was used to measure the height with a precision of $0.1 \mathrm{~cm}$, body weight was measured through System NY, Shirley; during the measurements they were barefoot and carying no metal on. Measurements were applied at the beginning of the season. Height, body weight and isokinetic leg strength were measured on the first day of the study, and isokinetic shoulder strength was measured on the second day.

\section{Isokinetic Leg Strenght Test}

The lower limb isokinetic muscle strength of female volleyball players participating in the study was measured with a Biodex brand isokinetic dynamometer (Biodex 3 Pro Medical System NY, Shirley). The volleyball players were warmed up for a total of 10 minutes before the test along with the streching movements towards the lower extremity. All volleyball players' bodies and knee zones were fixed to the seat with bands and standardized. Volleyball players were subjected to a concentricconcentric isokinetic knee strength test consisting of 10 repetitions at $180^{\circ} \mathrm{s}^{-1}$ angular speed and 5 repetitions at $60^{\circ} \mathrm{s}^{-1}$ angular velocity on both legs. Before the test started, volleyballers were given 3 trials at both angular speeds. The measurements were given a resting time of $3 \mathrm{~min}$ between both legs and $60 \mathrm{sec}$ between each angular velocity.

\section{Isokinetic Shoulder Internal and External Strength Test}

The upper extremity (shoulder) isokinetic muscle strength of the female volleyball players participating in the study were measured with a Biodex brand isokinetic dynamometer (Biodex 3 Pro Medical System NY, Shirley). Volleyball players were given a warming program for the upper extremity for 10 minutes before the test. All volleyball players' bodies were fixed to the seat with tapes and standardized. Concentric-concentric isokinetic shoulder strength test consisting of 10 repetitions at $60^{\circ} \mathrm{S}^{-1}$ angular velocity and $180^{\circ} \mathrm{s}^{-1}$ angular velocity was applied at $90^{\circ}$ abduction of the shoulder, $90^{\circ}$ flexion of the shoulder, and $90^{\circ}$ flexion of the wrist, while the neutral fingers were in the flexion position. Before the test started, the volleyball players were given 3 trials at both angular speeds. The measurements were given a resting time of $3 \mathrm{~min}$ between each shoulder and 60 seconds between each angular velocity.

\section{Statistical Analysis}

The mean and standard deviations of PT, BLDs, leg H/Q ratio, and shoulder E/I ratios of leg and shoulder muscles were determined after the obtained data were applied to the SPSS 24 software program.

\section{RESULTS}

Table 1. Demographic characteristics of female volleyball players $(n=14)$.

\begin{tabular}{lcccc}
\hline Variables & Min & Max & Mean & SD \\
\hline Age (year) & 17.6 & 23.1 & 20.3 & 1.54 \\
Height $(\mathrm{cm})$ & 168 & 191 & 182.78 & 6.45 \\
Weight $(\mathrm{kg})$ & 51 & 79 & 67.5 & 7.18 \\
BMI $\left(\mathrm{kg} / \mathrm{m}^{2}\right)$ & 15 & 24 & 21.78 & 5.8 \\
\hline
\end{tabular}

Table 2. D and ND hamstring and quadriceps muscle PTs at $60^{\circ} \mathrm{s}^{-1}$ and $180^{\circ} \mathrm{s}^{-1}$ angular speed of female volleyball players.

\begin{tabular}{lcccc}
\hline$(\mathrm{Nm})$ & Mean & SD & Min & Max \\
\hline $\mathrm{D} 60^{\circ} \mathrm{s}^{-1} \mathrm{PTQ}$ & 180.6 & 33.4 & 120 & 226.9 \\
$\mathrm{ND} 60^{\circ} \mathrm{s}^{-1} \mathrm{PTQ}$ & 173.1 & 30.1 & 114.3 & 213.3 \\
$\mathrm{D} 60^{\circ} \mathrm{s}^{-1} \mathrm{PT}$ & 90.1 & 14.9 & 60.3 & 108.9 \\
$\mathrm{ND} 60^{\circ} \mathrm{s}^{-1} \mathrm{PTH}$ & 94.1 & 17.4 & 63.3 & 132.9 \\
$\mathrm{D} 180^{\circ} \mathrm{s}^{-1} \mathrm{PTQ}$ & 120.0 & 21.5 & 77.6 & 155.9 \\
$\mathrm{ND} 180^{\circ} \mathrm{s}^{-1}$ & 116.1 & 19.1 & 75.5 & 150.5 \\
$\mathrm{PTQ}$ & 65.9 & 12.3 & 44 & 84.5 \\
$\mathrm{D} 180^{\circ} \mathrm{s}^{-1} \mathrm{PTH}$ & 65.2 & 12.9 & 46.5 & 91.5 \\
$\mathrm{ND} 180^{\circ} \mathrm{s}^{-1}$ & & & & \\
$\mathrm{PT} H$ & & & &
\end{tabular}


Table 3. D and ND H/Q ratio and BLD at $60^{\circ} \mathrm{s}^{-1}$ and $180^{\circ} \mathrm{s}^{-1}$ angular speed of female volleyball players.

\begin{tabular}{lcccc}
\hline$(\mathrm{Nm})$ & Mean & $\mathrm{SD}$ & Min & Max \\
\hline $\mathrm{D} 60^{\circ} \mathrm{s}^{-1} \mathrm{H} / \mathrm{Q}$ & 50.5 & 7.5 & 37.5 & 68.7 \\
$\mathrm{ND} 60^{\circ} \mathrm{s}^{-1} \mathrm{H} / \mathrm{Q}$ & 55.1 & 9.7 & 39.1 & 74.1 \\
$\mathrm{BLD} 60^{\circ} \mathrm{s}^{-1} \mathrm{Q}$ & 6.3 & 4.8 & 1.3 & 17.5 \\
$\mathrm{BLD} 60^{\circ} \mathrm{s}^{-1} \mathrm{H}$ & 12.6 & 19.2 & 0 & 35.6 \\
$\mathrm{D} 180^{\circ} \mathrm{s}^{-1} \mathrm{H} / \mathrm{Q}$ & 55.5 & 8.9 & 45.1 & 75.4 \\
$\mathrm{ND} 180^{\circ} \mathrm{s}^{-1} \mathrm{H} / \mathrm{Q}$ & 56.9 & 10.4 & 40.3 & 75.6 \\
$\mathrm{BLD} 180^{\circ} \mathrm{s}^{-1} \mathrm{Q}$ & 5.5 & 3.9 & 0.5 & 12.2 \\
$\mathrm{BLD} 180^{\circ} \mathrm{s}^{-1} \mathrm{H}$ & 9.1 & 6.3 & 2.4 & 24.2 \\
\hline
\end{tabular}

Table 4. D and ND shoulder external and internal rotation PTs at $60^{\circ} \mathrm{S}^{-1}$ and $180^{\circ} \mathrm{S}^{-1}$ angular speeds of female volleyball players.

\begin{tabular}{|c|c|c|c|c|}
\hline$(\mathrm{Nm})$ & Mean & SD & Min & Max \\
\hline $\mathrm{D} 60^{\circ} \mathrm{s}^{-1} \mathrm{PTE}$ & 25.7 & 5.8 & 15.4 & 38.7 \\
\hline $\mathrm{ND} 60^{\circ} \mathrm{s}^{-1} \mathrm{PT} \mathrm{E}$ & 29.0 & 12.3 & 15.9 & 66.7 \\
\hline $\mathrm{D} 60^{\circ} \mathrm{s}^{-1} \mathrm{PT} \mathrm{I}$ & 36.5 & 9.4 & 24.4 & 54.5 \\
\hline $\mathrm{ND} 60^{\circ} \mathrm{s}^{-1} \mathrm{PT}_{\mathrm{I}}$ & 32.7 & 7.2 & 20.9 & 47.1 \\
\hline $\mathrm{D} 180^{\circ} \mathrm{S}^{-1} \mathrm{PTE}$ & 23.7 & 4.9 & 16.3 & 32.1 \\
\hline $\mathrm{ND} 180^{\circ} \mathrm{s}^{-1} \mathrm{PTE}$ & 22.8 & 5.0 & 16.4 & 35.2 \\
\hline $\mathrm{D} 180^{\circ} \mathrm{s}^{-1} \mathrm{PT}_{\mathrm{I}}$ & 30.6 & 7.3 & 15.8 & 45.3 \\
\hline $\mathrm{ND} 180^{\circ} \mathrm{s}^{-1} \mathrm{PT}_{\mathrm{I}}$ & 28.5 & 6.0 & 19 & 39.8 \\
\hline
\end{tabular}

Table 5. D and ND shoulder E/I ratio and BLD at $60^{\circ} \mathrm{s}^{-1}$ and $180^{\circ} \mathrm{s}^{-1}$ angular speed of female volleyball players.

\begin{tabular}{lcccc}
\hline$(\mathrm{Nm})$ & Mean & SD & Min & Max \\
\hline $\mathrm{D} 60^{\circ} \mathrm{s}^{-1} \mathrm{E} / \mathrm{I}$ & 71.5 & 9.7 & 56.4 & 86.7 \\
$\mathrm{ND} 60^{\circ} \mathrm{s}^{-1} \mathrm{E} / \mathrm{I}$ & 89.6 & 37.7 & 63.4 & 98.4 \\
$\mathrm{BLD} 60^{\circ} \mathrm{s}^{-1} \mathrm{E}$ & 24.1 & 6.5 & 0.2 & 24.3 \\
$\mathrm{BLD} 60^{\circ} \mathrm{s}^{-1} \mathrm{I}$ & 12.9 & 8.1 & 0.4 & 25.1 \\
$\mathrm{D} 180^{\circ} \mathrm{s}^{-1} \mathrm{E} / \mathrm{I}$ & 79.6 & 15.5 & 48.8 & 92.8 \\
$\mathrm{ND} 180^{\circ} \mathrm{s}^{-1} \mathrm{E} / \mathrm{I}$ & 81.7 & 15.1 & 57.4 & 104.7 \\
$\mathrm{BLD} 180^{\circ} \mathrm{s}^{-1} \mathrm{E}$ & 7.6 & 7.2 & 0.9 & 23 \\
$\mathrm{BLD} 180^{\circ} \mathrm{s}^{-1} \mathrm{I}$ & 12.2 & 7.0 & 0.7 & 22.5 \\
\hline
\end{tabular}

\section{DISCUSSION}

Although the upper extremity visually seems to be doing more work in volleyball, the lower limb strength is more important than the upper extremity (27), such as leaping, sudden reversal, deception, stopping, sudden movements, high level balance and sprint movements in volleyball $(3,8,13)$ Therefore, the lower extremity knee flexor-extensor muscle strengths are low and the strength balance between these muscles is insufficient, and thus leading to high performance of the basic movements of the volleyball sport (spike, block and cuff rust). 
In the current literature, it was determined that the BLD was among the desired levels, while the H/Q ratio of the female volleyball players was found to be below the desired level.

Yenigün et al. (27) suggested that the volleyball players' findings in their study related to $\mathrm{H} / \mathrm{Q}$ ratio $\left(60^{\circ} \mathrm{s}^{-1} \% 48,180^{\circ} \mathrm{s}^{-1} 51 \%\right)$ were similar to those that were found the current study. Magalhaes et al. (16) investigated the difference between the isokinetic $\mathrm{H} / \mathrm{Q}$ ratio and BLD of volleyball players and footballers, they determined that $\mathrm{H} / \mathrm{Q}$ ratio of volleyball players was lower than that of soccer players; besides, he also found that volleyball BLD was at desired levels. Magalhaes et al. (16) concludes that the H/Q difference between volleyball players and soccer players is due to the fact that volleyballs have lower quadriceps PT. In a study determining the difference between the $H / Q$ ratios of two different players, Cheung et al. (7) found that $H / Q$ ratios of field (soccer) players were higher than court players (volleyball and basketball). Rosene et al. (20) found that the $H / Q$ ratio of female volleyball players was lower than the desired level in the study of $H / Q$ ratio of athletes in different branches.

The results of the above mentioned studies support the results of the current study and it is determined that the volleyball players have low $\mathrm{H} / \mathrm{Q}$ ratio. When the jump movement is examined in general, the quadriceps group muscles of the upper leg are required to actively contract to perform the separating movement (23).

Considering that elite volleyball players jump 150 times during a match on average (14), and considering that they exercise their jumps during training, it can be concluded that the increase in the quadriceps strength of the volleyballs reduces the $\mathrm{H} / \mathrm{Q}$ ratio.

This low H/Q ratio found in volleyball players may lead to an increased knee injury sensitivity, with particular emphasis on stress on the anterior cruciate ligament (ACL) due to decreased joint stability (16). In addition, the low BLD of volleyball player makes it clear that volleyball players can use both legs equally during training and that they may be associated with exercising a correct force.

It is a well-known fact that volleyball injuries are common in sports in general. To support this, a recently conducted study has demonstrated that volleyball injuries are the fourth most common among the acute sport injuries. Although the majority of injuries are found to be within the lower extremities, shoulder lesions are common $(21,22)$. Amongst the most common shoulder lesions, there are overuse injuries in the rotator cuff. It has also been demonstrated that there exist a surprisingly high frequency of suprascapular neuropathy with infraspinatus atrophy and weakness of external rotation of the shoulder amongst volleyball players $(9,11)$

In general, both agonists and antagonists believe that muscle weakness and aggravation of muscle strength between may be caused by such injuries (12).

When the literature was investigated, Alfredson et al. (2) found that female volleyball players had 72 $\%$ of the shoulder E/I ratio of, $79 \%$ of the shoulder E/I ratio and Hadziç et al. (10) determined that the players had $74 \%$ of the shoulder E/I ratio and $71 \%$ of the shoulder $\mathrm{E} / \mathrm{I}$ ratio In studies conducted on male volleyball players, Witvrow et al. (26) determined that the players had shoulder E/I ratio as $67 \%$, ND shoulder E/I ratio as $68 \%$ and Wang et al (24) found that players had $\mathrm{D}$ shoulder $\mathrm{E} / \mathrm{I}$ ratio as $67 \% \mathrm{ND}$ shoulder E/I ratio as $98 \%$. Both results and the results in the current literature reveal that shoulder E/I ratios are at the desired level.

When the studies conducted related to volleyball players' BLD were investigated, Wang et al. (24) determined that the players had shoulder internal rotation BLD $13.4 \%$, shoulder external rotation BLD $23.4 \%$, Wang \& Cochrane determined that players had shoulder internal rotation BLD 15.9 $\%$, shoulder external rotation BLD $22 \%$. In the current study, BLD was found to be high in shoulder internal and external muscles. This may be related to the fact that the athletes actively perform their actions such as serving, and doing more with the side they use.

As a conclusion, elite female volleyball players have good shoulder $\mathrm{E} / \mathrm{I}$ ratios and poor $\mathrm{H} / \mathrm{Q}$ ratios. In addition, the BLD of the knee muscles is between the desired limits while the BLD of the shoulder muscles is above the critical limit.

\section{REFERENCES}

1. Alexander MJL. Peak torque values for antagonist muscle groups and concentric and eccentric contraction types for elite sprinters. Arch Phys Med Rehabil, 1990; 71(5): 334-339.

2. Alfredson H, Pietila T, Lorentzon R. Concentric and eccentric shoulder and elbow muscle strength in female volleyball players and non-active females. Scand J Med Sci Sports, 1998; 8(5-1): 265-270.

3. Almeida TA, Soares EA. Nutritional and anthropometric profile of adolescent volleyball athletes. Rev Bras Med Esporte, 2003; 9(4): 198-203. 
4. Astrand PO, Rodahl K, Dahl AH, Stromme BS. Textbook of Work Phyiology, Human Kinetics, Australia, 2003.

5. Beneka A, Malliou P, Ispirlidis I, Godolias G, Alexopoulos P. Restoration of muscles imbalances with a spesific strength training program in young players, 5 th World Congress on Science and Football, Human Kinetcs Technical University of Lisbon, Lisbon, 2003, 330-335.

6. Burket LN. Causative factors in hamstring strains. Med Sci Sport Exer, 1970; 2(1): 39-42.

7. Cheung R, Andrew S, Del W. H:Q ratios and bilateral leg strength in college field and court sports players. J Hum Kinetics, 2012, 33: 63-71.

8. Dal Pupo J, Detanico D, dos Santos SG. Kinetic parameters as determinants of vertical jump performance. Braz. J Kinathrop Hum Perform, 2012; 14(1): 41-51.

9. Ferretti A, Cerullo G, Russo G. Suprascapular neuropathy in volleyball players. J Bone Joint Surg, 1987; 69(2): 260-263.

10. Hadzic V, Sattler T, Veselko M, Markovic G, Dervisevic E. Strength asymmetry of the shoulders in elite volleyball players. J Athl Train, 2014; 49(3): 338-344.

11. Holzgraefe M, Kukowski B, Eggert S. Prevalence of latent and manifest suprascapular neuropathy in high-perform- ance volleyball players. Br J Sports Med, 1994: 28(3): 177-179.

12. Ivey FM, Calhoun JH, Rusche K, Bierschenk J. Isokinetic testing of shoulder strength: normal values. Arch Phys Med Rehabil, 1985: 66(6): 384-386.

13. İbiş $S$, İri R, Aktuğ ZB. The effect of female volleyball players' leg volume and mass on balance and reaction time. Journal of Human Sciences, 2015; 12(2) 1296-1308.

14. Kalaycı A. Voleybol sakatlıkları. I. Voleybol Bilim ve Teknoloji Dergisi, 1996; 3(8): 33-38.

15. Lindenfeld TN, Schmitt DJ, Hendy MP, Mangine RE, Noyes FR. Incidence of injury in indoor soccer. Am J Sports Med, 1994; 22(3): 364-371.

16. Magalhaes J, Oliveira J, Ascensao A, Soares J. Concentric quadriceps and hamstrings isokinetic strength in volleyball and soccer players, J Sports Med Phys Fitness, 2004; 44(2): 119125 .
17. Miller KE, Pierson LM, Richardson SM, Wootten DF, Selmon SE, Ramp WK, Herbert WG. Knee extensor and flexor torque development with concentric and eccentric isokinetic training. Res Q Exerc Sport, 2006; 77(1): 58-63.

18. Olyaei GR, Hadian MR, Talebian S, Bagheri H, Malmir K. The effect ofmusclefatigue onknee flexsor and extensor torquoe ratio and knee dynamic stability. Arab J Sci Eng, 2006; 31(2): 121-127.

19. Renstrom P, Ljungqvist A, Arendt E, Beynnon B, Fukubayashi $T$, Garrett W, ... Engebretsen L. Non-contact ACL injuries in female athletes: an International Olympic Committee current concepts statement. Br J Sports Med, 2008; 42(6): 394-412.

20. Rosene JM, Fogarty TD, Mahaffey BL. Isokinetic hamstrings/quadriceps ratio in intercollegiate athletes, J Athl Train, 2001; 36(4): 378-383.

21. Schafle MD. Common injuries in volleyball. Sports Med, 1993: 16(2): $126-129$

22. Solgard L, Buhl Nielsen A, Mdler-Madsen B, Wulff Ja- cobsen B, Yde J, Jensen J. Volleyball injuries presenting in casualty. A prospective study. Br J Sports Med, 1995; 29(3): 200-204.

23. Şimşek B, Ertan H, Göktepe AS, Yazıcıoğlu K. The effects of knee muscle strenght on jumping height in female volleyball paleyers. Egzersiz, 2007; 1(1): 36-43.

24. Wang $\mathrm{H}$, Macfarlane $\mathrm{A}$, Cochrane T. Isokinetic performance and shoulder mobility in elite volleyball athletes from the United Kingdom. Br J Sports Med, 2000; 34(1): 39-43.

25. Wang HK, Cochrane T. Mobility impairment, muscle imbalance, muscle weakness, scapular asymmetry and shoulder injury in elite volleyball athletes. J Sports Med Phys Fitness, 2001; 41(3): 403-410.

26. Witvrouw E, Cools A, Lysens R, Cambier D, Vanderstraeten G, Victor J, Sneyers C, Walravens M. Suprascapular neuropathy in volleyball players. Br J Sports Med, 2000; 34(3): 174-180.

27. Yenigün Ö, Çolak T, Bamaç B, Yenigün N, Özbek A, Bayazıt B, Çolak E. Voleybol oyuncularının diz ekleminin izokinetik performans değerleri ve hamstring (fleksör). Quadriceps (ekstansör) oranlarındaki farklllıkların belirlenmesi, Journal of Human Sciences, 2008; 5(1): 1-13. 